\title{
Impact of Odd-Even Driving Restrictions on Air Quality in Jakarta
}

\author{
Zulkarnain $^{1 *}$, Al Ghiffary ${ }^{1}$ \\ ${ }^{1}$ Departement of Industrial Engineering, Faculty of Engineering, Universitas Indonesia, Kampus UI Depok, \\ Depok 16424, Indonesia
}

\begin{abstract}
Governments often enact driving restrictions through transportation demand management programs to solve traffic congestion and air pollution problems in a city or region by prohibiting the public from using their private vehicles during certain days. Driving restrictions are quite prevalent in cities in which many private cars are operated, including DKI Jakarta, where such a program has been implemented for several years. The purpose of this study is to estimate the effect or impact of the expansion of odd-even driving restrictions on DKI Jakarta's ambient air quality. Carried out by regression discontinuity design, this study found that the odd-even driving restrictions do not significantly reduce DKI Jakarta's air pollutants. Several factors that affect the restrictions' impact include the restrictions' selective mechanism and compensating response managed by the public. Thus, the government should improve the restriction mechanism or enact more impactful programs to solve the air quality problem in DKI Jakarta.
\end{abstract}

Keywords: Air quality; Driving restrictions; Regression discontinuity design; Transportation demand management

\section{Introduction}

Air pollution has been considered one of the most concerning environmental issues around the world. The high concentration of air pollutants leads to several negative impacts on human health. In 2016, outdoor air pollution resulted in an estimated 4.2 million premature deaths worldwide, with about $91 \%$ of those premature deaths occurring in lowand middle-income countries, particularly in South-East Asia and Western Pacific regions (World Health Organization, 2018).

DKI Jakarta has been struggling to solve the air quality problem in recent years. The air quality of DKI Jakarta, Indonesia, has deteriorated, with the $\mathrm{PM}_{2.5}$ average concentration escalating to $49.4 \mu \mathrm{g} / \mathrm{m}^{3}$ in 2019 , which is about 66\% higher than in 2017 (IQ Air, 2019). This concentration is almost five times as much as the $\mathrm{PM}_{2.5}$ annual mean guideline established by the World Health Organization. Motor vehicles have become the primary source of pollution in DKI Jakarta. In particular, the contribution of motor vehicles to the $\mathrm{PM}_{2.5}$ concentration of DKI Jakarta is approximately 32-57\% (Vital Strategies, 2020). This is due to the rapid motorization of DKI Jakarta and its surrounding regions. The number of motor vehicles in DKI Jakarta has continued to surge to 22.8 million units in 2019, which includes 1.6 million and 407,000 additional motorcycles and private cars, respectively, during the last two years (Central Bureau of Statistics, 2020). Even after the enhancement 
of public transportation, Syafrizal et al. (2016) estimated that the number of motor vehicles operated in DKI Jakarta is still expected to grow by at least $120 \%$ between 2011 and 2021 .

An intelligent transportation system, which is the adoption and application of modern information and communications technology, and the deployment of electric vehicles in the vehicle market are some of the prospective alternatives for resolving traffic challenges and carbon footprint problems (Zulkarnain et al., 2012; Leviäkangas, 2013). Moreover, transport policies have become primary strategies for mitigating climate change impacts (Leviäkangas, 2013). Thus, to accelerate the implementation of air quality control in DKI Jakarta Province, the government issued the DKI Jakarta Governor's Instruction (InGub) No. 66,2019 , regarding air quality control. The DKI Jakarta government plans to rectify the ambient air quality issue through various programs and policies that hopefully may control the sources of air pollution, encourage the public to alter their lifestyle by utilizing public transportation, and optimize the city's reforestation efforts.

As part of the instructions, the government implemented odd-even driving restrictions, a traffic management system enacted by the government of DKI Jakarta to curtail the travel of passenger cars on certain roads based on the vehicle license number. The program was first implemented on August 30, 2016, on nine roads around DKI Jakarta and was expanded to cover 25 roads on September 9, 2019. The restrictions are enforced from Monday to Friday from 06.00 to 10.00 UTC+07:00 (or Western Indonesia Time-WIB) and from 16.00 to $21.00 \mathrm{WIB}$. The government believes this action will yield positive impacts on solving traffic congestion and air pollution problems. Several studies have implied that transportation demand management (TDM) based on vehicle operating restrictions has been proven to reduce pollutant emissions by more than 50\% (Bigazzi and Rouleau, 2017).

Although several studies have argued that such a program can alleviate traffic congestion and air pollution, the real implementations in some regions show the opposites. Some studies have suggested positive findings of driving restrictions on improving urban air quality. For instance, Viard and Fu (2015) evaluated the one-day-per-week restriction in Beijing, and their findings suggest that the restriction succeeded in reducing air pollution by $21 \%$ after implementation. Conversely, Ye's (2017) findings in Lanzhou suggest that the restriction did not improve air quality and caused the public to adapt to the restriction by acquiring secondary vehicles.

Odd-even driving restrictions have been implemented, though on a limited scale, in cities worldwide, including in China, India, Indonesia, Philippines, and Central/Latin America (Farda and Balijepalli, 2018). Specifically in Indonesia, several studies have been conducted regarding the impacts of DKI Jakarta's odd-even driving restrictions, albeit mostly on traffic congestion (Nafila, 2018; Yudhistira et al., 2019). Limited studies about transport policies' environmental impacts have also been conducted, one to evaluate overall low-carbon transportation policies in Southeast Asia (Bakker et al., 2017) and the other to specifically assess TDM programs' impacts in Bandung, Indonesia (Farda and Balijepalli, 2018). However, a study specifically dedicated to assessing the impacts of DKI Jakarta's oddeven driving restrictions on air quality has remained unavailable until now. Therefore, an empirical study is imperative to confirm the local government's claim that the driving restrictions implemented in DKI Jakarta positively impact urban air quality. This paper aims to estimate the impact of driving restrictions on several air pollution parameters in DKI Jakarta, Indonesia.

\section{Literature Review}

The World Health Organization (2006) defines air pollutants as particulate matter $(\mathrm{PM})$, ozone $\left(\mathrm{O}_{3}\right)$, nitrogen dioxide $\left(\mathrm{NO}_{2}\right)$, and sulfur dioxide $\left(\mathrm{SO}_{2}\right)$. Greenhouse gases are 
defined as carbon dioxide $\left(\mathrm{CO}_{2}\right)$, nitrous oxide $\left(\mathrm{NO}_{2}\right)$, methane $\left(\mathrm{CH}_{4}\right)$, and fluorine gas. Carbon monoxide ( $\mathrm{CO}$ ) and volatile organic compounds, which are also included in the category of pollutants, are also often considered in air quality monitoring because they are closely related to the formation of $\mathrm{O}_{3}$ and PM (Melamed et al., 2016). These air pollutants and greenhouse gases are parameters or indicators of air quality that are commonly used in any region around the world. Each indicator has daily and annual standards set by the World Health Organization and must be met by local governments. In simple terms, each region must try to maintain its air quality by emphasizing the concentration of each pollutant indicator below the specified limit in order to reduce various negative impacts caused by these pollutants and gases, especially in terms of health. Specifically, for DKI Jakarta, indicators commonly used to monitor air quality are particulate-matter-2.5 ( $\left.\mathrm{PM}_{2.5}\right)$, particulate-matter-10 ( $\left.\mathrm{PM}_{10}\right)$, sulfur oxides $\left(\mathrm{SO}_{2}\right), \mathrm{CO}, \mathrm{O}_{3}$, and $\left(\mathrm{NO}_{2}\right)$.

Air pollutants and greenhouse gases can have a negative impact on human health. PM is the cause of many diseases, such as heart attacks, asthma, and lung malfunctions, and can cause symptoms of respiratory diseases (Atkinson et al., 2010; Meister et al., 2012; Correia et al., 2013; Fang et al., 2013; Cadelis et al., 2014). Exposure to PM2.5 air pollutants can also increase premature birth, low body mass of babies during childbirth, and infant mortality (Stieb et al., 2012; Nieuwenhuijsen et al., 2013; Pedersen et al., 2013; Proietti et al., 2013). According to Vallero (2014), not only PM but also other air pollutants can cause various acute and chronic respiratory diseases that range from mild irritation, inflammation, allergic reactions to respiratory failure diseases (e.g., chronic obstructive pulmonary disease), heart disease, asthma, and various types of cancer.

Regression discontinuity design (RDD) is a quasi-experimental design with the characteristic that the probability of receiving treatment changes discontinuously as a function of the variable (Hahn et al., 2001). This design can estimate the impact or effect of a treatment on variables commonly used in program evaluation research or policy analysis by selecting a cut-off value as a threshold between the observations without treatment and with treatment (Lee and Lemieux, 2010). RDD is one of the leading choices in program evaluation or policy analysis because it requires only a few mild assumptions compared to other non-experimental approaches, and the approach is considerably more credible for causal deduction than other approaches like the difference-in-difference method (Lee and Lemieux, 2010).

Several studies have used RDD to study the impact of driving restrictions in some capitals and megacities (Davis, 2008; Viard and Fu, 2015; Huang et al., 2017; Zhang et al. 2020). Although the method is commonly prevalent in studies on economics, an increasing number of studies have used RDD to estimate the treatment effects of environmental and energy policies (Hausman and Rapson, 2018). For several reasons, including the unavailability of cross-sectional variation in the restriction implementation, the availability of ambient air quality data at a daily or hourly frequency, and the existence of many potential time-varying confounders, researchers have been encouraged to utilize RDD design to estimate the impacts of an environmental program or policy implementation.

\section{Estimation Strategy}

An RDD was conducted with time as the forcing variable to estimate the causal impacts of the odd-even driving restriction on air quality. First, the necessary data were collected, which comprised daily air pollutants and meteorological conditions. Furthermore, required assumptions were checked based on the recommendations of Hausman and Rapson (2018). The results of the assumption check determined the model specification to be used for 
estimating the causal impacts of the restriction on air pollutant concentrations of DKI Jakarta.

\subsection{Data}

For the study, we collected a data set containing daily air pollutants and meteorological conditions. The air pollutants included $\mathrm{PM}_{2.5}, \mathrm{PM}_{10}, \mathrm{SO}_{2}, \mathrm{CO}, \mathrm{O}_{3}$, and $\mathrm{NO}_{2}$, which were obtained from AirNow - an air quality monitoring firm - and the DKI Jakarta Environmental Agency. AirNow's monitoring stations are owned by the United States Embassy located in Central and South Jakarta and only capture daily $\mathrm{PM}_{2.5}$ concentrations. The monitoring stations owned by the DKI Jakarta government are located in five areas, including Bundaran HI (Central Jakarta), Kelapa Gading (North Jakarta), Jagakarsa (South Jakarta), Lubang Buaya (East Jakarta), and Kebon Jeduk (West Jakarta), and provide the daily concentrations for $\mathrm{PM}_{10}, \mathrm{SO}_{2}, \mathrm{CO}, \mathrm{O}_{3}$, and $\mathrm{NO}_{2}$.

The air pollutants data were supplemented by meteorological data from two monitoring stations located in Kemayoran (Central Jakarta) and Tanjung Priok (North Jakarta), which are owned by the Meteorology, Climatology, and Geophysical Agency of Indonesia (BMKG). The meteorological data include several weather conditions, such as average temperature, average humidity, wind speed, and rainfall. The meteorological data were performed as control variables, as the involvement of covariates in RDD is essential, especially to reduce bias (Frölich, 2007; Hausman and Rapson, 2018). Additionally, several dates, such as weekends and national holidays, were also considered as another control variable for the model. Detailed variable definitions and descriptive statistics are exhibited in Table 1.

Table 1 Number of receptors in each container

\begin{tabular}{llrr}
\hline \multicolumn{1}{c}{ Variable } & \multicolumn{1}{c}{ Definition } & Mean & SD \\
\hline $\mathrm{PM}_{2.5}$ & $\mathrm{PM}_{2.5}$ concentration $\left(\mu \mathrm{g} / \mathrm{m}^{3}\right)$ & 47.58 & 8.55 \\
$\mathrm{PM}_{10}$ & $\mathrm{PM}_{10}$ concentration $\left(\mu \mathrm{g} / \mathrm{m}^{3}\right)$ & 65.10 & 5.92 \\
$\mathrm{SO}_{2}$ & $\mathrm{SO}_{2}$ concentration $\left(\mu \mathrm{g} / \mathrm{m}^{3}\right)$ & 18.60 & 1.53 \\
$\mathrm{CO}$ & $\mathrm{CO}$ concentration $\left(\mu \mathrm{g} / \mathrm{m}^{3}\right)$ & 14.75 & 3.19 \\
$\mathrm{O}_{3}$ & $\mathrm{O}_{3}$ concentration $\left(\mu \mathrm{g} / \mathrm{m}^{3}\right)$ & 89.07 & 21.51 \\
$\mathrm{NO}_{2}$ & $\mathrm{NO}_{2}$ concentration $\left(\mu \mathrm{g} / \mathrm{m}^{3}\right)$ & 9.94 & 1.87 \\
$\mathrm{TEMP}$ & Average temperature $\left({ }^{\circ} \mathrm{C}\right)$ & 28.80 & 0.70 \\
$\mathrm{HUMI}$ & Average Humidity $(\%)$ & 69.85 & 3.60 \\
WIND & Wind Speed $(\mathrm{km} / \mathrm{h})$ & 1.77 & 0.34 \\
RAINFALL & Rainfall $(\mathrm{mm})$ & 0.39 & 3.07 \\
HOLIDAY & $=1$ if the observation is on a holiday; $=0$ otherwise & 0.28 & 0.45 \\
\hline
\end{tabular}

\subsection{Empirical Model}

Using time as the forcing variable, the estimation model used is as follows:

$$
\ln \left(Y_{t}\right)=\alpha+\tau D_{t}+\beta X_{t}+\delta W_{t}+\gamma Y_{t-1}+\varepsilon_{t}
$$

where $\ln \left(Y_{t}\right)$ represents the daily air pollutants converted to the natural logarithm and $\tau$ is the coefficient of interest that measures how air pollutants respond to driving restrictions. $D$ is a dummy variable that represents the treatment restrictions. $X_{t}$ is the forcing variable (also called a running variable) in the form of days and determines the value of the dummy variable $\mathrm{D}\left\{\begin{array}{l}1, X \geq c \\ 0, X<c\end{array}\right.$, meaning that the variable has a value of 1 for observations during oddeven restrictions (after implementation date), and 0 otherwise. $C$ is also known as the cutoff value, which acts as the threshold between the days before and after implementation. For this particular study, the cut-off value selected was per the implementation date of the 
expansion of the driving restriction, which was September 9, 2019. $W_{t}$ represents the covariates or control variables, which comprise average temperature, average humidity, wind speed, rainfall, and holidays. $Y_{t-1}$ is the lagged dependent variable, and $\varepsilon_{t}$ is the error term. The optimal bandwidth selection method developed by Imbens and Kalyanaraman (2012) was used in the estimation.

Before proceeding to the estimation process, several assumptions have to be checked, and if any violation existed, we applied remedies to minimize potential bias. These assumptions were based on several previous studies regarding the RDD. The first assumption was checked by conducting a discontinuity test in the covariates around the lockdown dates (Hahn et al., 2001). The results, presented in Table 2, show no significant discontinuity of control variables at the cut-off date.

Table 2 Odd-even restriction impacts on meteorological conditions

\begin{tabular}{ccccc}
\hline & TEMP & HUMIDITY & WIND & RAINFALL \\
\hline Odd-Even & -0.321 & -2.611 & -0.314 & 0.007 \\
Restriction & $(0.434)$ & $(3.984)$ & $(0.302)$ & $(0.005)$ \\
\hline
\end{tabular}

Note: Value inside parenthesis are clustered robust standard error.

Furthermore, by using time as the forcing variable, the estimation process encounters several challenges due to its dependence on variations in time series data that may lead to serial correlation (Hausman and Rapson, 2018). Thus, following the previous studies, standard errors will be clustered based on the near neighbor rule. Yet, even after considering the serial correlation in errors, autoregression can also occur in the dependent variable (Hausman and Rapson, 2018). This is due to the varying duration of air pollutant dissipation; the pollutants may remain in the atmosphere even after the day changes (MacDonnel et al., 2013). Consequently, autoregression on the dependent variable was estimated using the autoregressive model AR(1). The results, presented in Table 3, indicate that the air pollutant concentration on the previous day affects the next day's pollutant concentration significantly. Hence, to minimize bias, the lagged dependent variable was included in the model, as shown in Equation 1.

Table 3 Autoregression coefficient on dependent variable

\begin{tabular}{ccccccc}
\hline & $\mathrm{PM}_{2.5}$ & $\mathrm{PM}_{10}$ & $\mathrm{SO}_{2}$ & $\mathrm{CO}$ & $\mathrm{O}_{3}$ & $\mathrm{NO}_{2}$ \\
\hline $\begin{array}{c}\text { Autoregression } \\
\text { coefficient }\end{array}$ & $\begin{array}{c}0.542^{* * *} \\
(0.077)\end{array}$ & $\begin{array}{c}0.257^{* * *} \\
(0.035)\end{array}$ & $\begin{array}{c}0.492^{* * *} \\
(0.079)\end{array}$ & $\begin{array}{c}0.306^{* * *} \\
(0.088)\end{array}$ & $\begin{array}{c}0.349^{* * *} \\
(0.085)\end{array}$ & $\begin{array}{c}0.539^{* * *} \\
(0.078)\end{array}$ \\
\hline
\end{tabular}

Note: ${ }^{* * *} \mathrm{p}<0.01,{ }^{* *} \mathrm{p}<0.05,{ }^{*} \mathrm{p}<0.1$. Value inside parentheses are clustered robust standard error.

The estimation of the impacts of odd-even driving restrictions on air quality was conducted after all imperative assumptions were checked and remedies were applied. Furthermore, we conducted a robustness check by performing a placebo test (Hausman and Rapson, 2018) similar to RDD, albeit using the driving restriction trial date as the cut-off value instead of the real implementation date. This approach was conducted because any enacted program or policy is usually tested before official implementation. The expansion of the odd-even restriction in DKI Jakarta was previously tested in a trial period from August 12 to September 6, 2019. Hence, the placebo test was carried out to estimate the 
impacts of the driving restriction expansion trials on the air pollutants because there was a possibility that premature changes in air pollutant concentrations could occur.

\section{Results and Discussion}

Table 4 presents the estimation results of the treatment effects for Equation 1. Identical to the results of driving restrictions from other cities, such as those in Davis (2008), Cao et al. (2014), and Huang et al. (2017), the odd-even restrictions do not significantly improve the air quality of DKI Jakarta. After the official driving restrictions, all tested pollutants contradictorily indicate a moderate increase of concentrations, although the coefficients are statistically insignificant. Compared to the results of the placebo test reported in Table 5, the treatment effects of restriction trials show negative impacts on several air pollutants. Apart from $\mathrm{PM}_{2.5}$, the $\mathrm{PM}_{10}, \mathrm{SO}_{2}, \mathrm{CO}, \mathrm{O}_{3}$, and $\mathrm{NO}_{2}$ concentrations after the trial period indicate varying decreases of $0.2 \%, 6 \%, 6.7 \%, 19.7 \%$, and $10.5 \%$, respectively, albeit only the $\mathrm{SO}_{2}$ concentration shows a significant reduction with a $99 \%$ confidence interval.

Table 4 Odd-even restriction impacts on air pollutants

\begin{tabular}{ccccccc}
\hline & $\mathrm{PM}_{2.5}$ & $\mathrm{PM}_{10}$ & $\mathrm{SO}_{2}$ & $\mathrm{CO}$ & $\mathrm{O}_{3}$ & $\mathrm{NO}_{2}$ \\
\hline Odd-Even & 0.069 & 0.089 & 0.042 & 0.269 & 0.138 & 0.182 \\
Restriction & $(0.110)$ & $(0.055)$ & $(0.053)$ & $(0.213)$ & $(0.136)$ & $(0.173)$ \\
\hline
\end{tabular}

Note: Value inside parentheses are clustered robust standard error

This estimation included all control variables, such as average temperature, average humidity, wind speed, rainfall, weekends, and national holidays, along with lagged dependent variables, to alleviate autoregression in the air pollutants. In addition, the model also implemented heteroscedasticity-robust standard errors and clustered standard errors to deal with the problem of heteroscedasticity and serial correlation. Note that this estimation only refers to the expansion of ongoing restriction effective by September 9, 2019, so this estimation does not account for the first restriction applied on August 30, 2016.

Table 5 Placebo test

\begin{tabular}{lcccccc}
\hline & $\mathrm{PM}_{2.5}$ & $\mathrm{PM}_{10}$ & $\mathrm{SO}_{2}$ & $\mathrm{CO}$ & $\mathrm{O}_{3}$ & $\mathrm{NO}_{2}$ \\
\hline Official & 0.069 & 0.089 & 0.042 & 0.269 & 0.138 & 0.182 \\
Implementation & $(0.110)$ & $(0.055)$ & $(0.0053)$ & $(0.213)$ & $(0.136)$ & $(0.173)$ \\
Trial Period & 0.036 & -0.002 & $\mathbf{- 0 . 0 6 0 * * *}$ & -0.067 & -0.197 & -0.105 \\
& $(0.121)$ & $(0.064)$ & $(0.021)$ & $(0.158)$ & $(0.258)$ & $(0.208)$ \\
\hline
\end{tabular}

Note: ${ }^{* * *} \mathrm{p}<0.01,{ }^{* *} \mathrm{p}<0.05,{ }^{*} \mathrm{p}<0.1$. Value inside parentheses are clustered robust standard error

While the rest of the pollutants indicate some insignificant reductions, the coefficient of $\mathrm{PM}_{2.5}$ shows the opposite. $\mathrm{PM}_{2.5}$ is the only pollutant that indicates an insignificant increase after the implementation of the restrictions. This condition is due to limited access to available data and varying locations of monitoring stations. As mentioned in the estimation strategy, the $\mathrm{PM}_{2.5}$ concentration data were collected only from two monitoring stations located in Central and South Jakarta, owned by the United States Embassy. No more stations could provide open access to $\mathrm{PM}_{2.5}$ concentration data, as the local government only provides $\mathrm{PM}_{10}, \mathrm{SO}_{2}, \mathrm{CO}, \mathrm{O}_{3}$, and $\mathrm{NO}_{2}$ data for public use.

Furthermore, the monitoring stations owned by the local government are not located in the same place as the $\mathrm{PM}_{2.5}$ monitoring station. The local government monitoring stations 
forPM $\mathrm{P}_{10}, \mathrm{SO}_{2}, \mathrm{CO}, \mathrm{O}_{3}$, and $\mathrm{NO}_{2}$ are located in Bundaran $\mathrm{HI}$ (Central Jakarta), Kelapa Gading (North Jakarta), Jagakarsa (South Jakarta), Lubang Buaya (East Jakarta), and Kebon Jeduk (West Jakarta). These circumstances may explain the differences in coefficient value between the $\mathrm{PM}_{2.5}$ and the rest of the pollutants.

An adequate number of monitoring stations could provide a more reliable and generalized pollutant concentration for the entire city. However, the lack of monitoring stations installed in DKI Jakarta is currently a real issue. The number of monitoring stations in DKI Jakarta and most Southeast Asian cities is relatively sparse, with several nongovernmental organizations contributing more than the local government in terms of monitoring air pollution (IQ Air, 2019). This condition has compelled several studies in the same field to use DKI Jakarta's $\mathrm{PM}_{2.5}$ concentration data from the same source (Kusumaningtyas et al., 2018; Kusuma et al., 2019; Hansun et al., 2021).

Overall, the odd-even driving restriction does not significantly improve the air quality of DKI Jakarta based on the results obtained. Several factors may play an influential role in affecting the impact of the driving restriction. First and foremost, the restriction does not apply to private motorcycles, which are the most popular transportation mode in DKI Jakarta, with a staggering number of 16.9 million units operating in DKI Jakarta during 2019. This number was approximately five times the number of private cars (4.2 million units) in DKI Jakarta, which leads to the unsolved problem of air pollution and ineffectiveness of the restriction in reducing air pollutants, as motorcycles are the primary contributor of pollutants, emitting at least $45 \%$ of DKI Jakarta's total air pollution, while passenger cars emit only around 14\% (Wuragil, 2019).

In addition, the odd-even driving restriction can initiate compensating responses by the public, including the purchase of a second vehicle to avoid restrictions or the selection of alternative transportation modes, such as non-private vehicles like online ride-hailing and taxi services. This response can be seen through the surge in private vehicle ownership during 2017-2019, which reached a total of 22.8 million units (Central Bureau of Statistics, 2020). The results of several studies in other cities have also shown an increase in the purchase of private cars in those areas after the implementation of similar driving restrictions (Davis, 2008).

In most developing countries, it has become apparent that the project planning process is prone to several procedural weaknesses, which have made the successful execution of such projects difficult (Hansen et al., 2018). DKI Jakarta's government must evaluate the implemented driving restriction program based on the previously mentioned issues to enhance the program's effectiveness in reducing air pollution. Therefore, a project must have adequate front-end planning, especially by undertaking a feasibility study to fully understand the project's mechanisms, requirements, and constraints (Hansen et al., 2018). Moreover, DKI Jakarta's government should cooperate with the national government to plan any program dedicated to tackling environmental issues because the collaboration between both parties will potentially yield more reduction in greenhouse gas emissions (Hidayatno et al., 2015).

\section{Conclusions}

The expansion of odd-even driving restrictions in DKI Jakarta has not succeeded in improving air quality. There was no significant reduction of air pollutants after the DKI Jakarta government carried out the restrictions. Several factors, such as the weakness of the restriction mechanism and the compensating public response, may restrain the impacts of the restriction on reducing DKI Jakarta's air pollutant concentrations. However, results from the placebo test may indicate premature effects of the restrictions during the trial 
period. The restriction has not shown a significant impact. Still, by considering the factors that concealed the actual and potential impact of air pollutant reduction, the government can evaluate and develop more improvements in the restriction mechanism or enact more impactful programs to solve the air quality problem in DKI Jakarta.

\section{Acknowledgements}

This study serves as the second author's final thesis, which was conducted to receive a Bachelor of Engineering (B. Eng) degree from the University of Indonesia. The authors would like to express appreciation and gratitude to the Directorate of Research and Development Universitas Indonesia for funding this study through PUTI Q1 Research Grants Universitas Indonesia No: NKB-1433/UN2.RST/HKP.05.00/2020. The authors would also like to express appreciation and gratitude to AirNow, the DKI Jakarta Environmental Agency, and BMKG for providing such crucial and valuable data.

\section{References}

Atkinson, R.W., Fuller, G.W., Anderson, H.R., Harrison, R.M., Armstrong, B., 2010. Urban Ambient Particle Metrics and Health: A Time-Series Analysis. Epidemiology, Volume 21(4), pp. 501-511

Bakker, S., Dematera Contreras, K., Kappiantari, M., Tuan, N.A., Guillen, M.D., Gunthawong, G., Zuidgeest, M., Liefferink, D., Van Maarseveen, M., 2017. Low-Carbon Transport Policy in Four ASEAN Countries: Developments in Indonesia, the Philippines, Thailand and Vietnam. Sustainability, Volume 9(7), pp. 1-17

Bigazzi, A.Y., Rouleau, M., 2017. Can Traffic Management Strategies Improve Urban Air Quality? A Review of the Evidence. Journal of Transport \& Health, Volume 7(Part B), pp. 111-124

Cadelis, G., Tourres, R., Molinie, J., 2014. Short-Term Effects of the Particulate Pollutants Contained in Saharan Dust on the Visits of Children to the Emergency Department Due to Asthmatic Conditions in Guadeloupe (French Archipelago of the Caribbean). PloS One, Volume 9(3), pp. 1-11

Cao, J., Wang, X., Zhong, X., 2014. Did Driving Restrictions Improve Air Quality in Beijing? China Economic Quarterly, Volume 13(3), pp. 1091-1126

Central Bureau of Statistics. 2020. Statistik Indonesia 2020 (Indonesia Statistics 2020). Statistical Yearbook of Indonesia

Correia, A.W., Pope III, C.A., Dockery, D.W., Wang, Y., Ezzati, M., Dominici, F., 2013. The Effect of Air Pollution Control on Life Expectancy in the United States: An Analysis of 545 US Counties for the Period 2000 to 2007. Epidemiology (Cambridge, Mass.), Volume 24(1), pp. 23-31

Davis, L.W., 2008. The Effect of Driving Restrictions on Air Quality in Mexico City. Journal of Political Economy, Volume 116(1), pp. 38-81

Fang, Y., Naik, V., Horowitz, L.W., Mauzerall, D.L., 2013. Air Pollution and Associated Human Mortality: The Role of Air Pollutant Emissions, Climate Change and Methane Concentration Increases from the Preindustrial Period to Present. Atmospheric Chemistry and Physics, Volume 13(3), pp. 1377-1394

Farda, M., Balijepalli, C., 2018. Exploring the Effectiveness of Demand Management Policy in Reducing Traffic Congestion and Environmental Pollution: Car-Free Day and Odd-Even Plate Measures for Bandung City in Indonesia. Case Studies on Transport Policy, Volume 6(4), pp. $577-590$ 
Frölich, M., 2007. Regression Discontinuity Design with Covariates. Discussion Paper, University of St. Gallen, Department of Economics (2007-32). Available Online at https://ftp.iza.org/dp3024.pdf

Hahn, J., Todd, P., Van der Klaauw, W., 2001. Identification and Estimation of Treatment Effects with a Regression-Discontinuity Design. Econometrica, Volume 69(1), pp. 201209

Hansen, S., Too, E., Le, T., 2018. Lessons Learned from a Cancelled Urban Transport Project in a Developing Country: The Importance of the Front-end Planning Phase. International Journal of Technology, Volume 9(5), pp. 898-909

Hansun, S., Wicaksana, A., Kristanda, M.B., 2021. Prediction of Jakarta City Air Quality Index: Modified Double Exponential Smoothing Approaches. International Journal of Innovative Computing, Information and Control, Volume 17(4), pp. 1363-1371

Hausman, C., Rapson, D.S., 2018. Regression Discontinuity in Time: Considerations for Empirical Applications. Annual Review of Resource Economics, Volume 10, pp. 533-552

Hidayatno, A., Rahman, I., Muliadi, R., 2015. Policy Analysis of the Jakarta Carbon Mitigation Plan using System Dynamics to Support Decision Making in Urban DevelopmentOptions for Policymakers. International Journal of Technology, Volume 5(8), pp. 886893.

Huang, H., Fu, D., Qi, W., 2017. Effect of Driving Restrictions on Air Quality in Lanzhou, China: Analysis Integrated with Internet Data Source. Journal of Cleaner Production, Volume 142, pp. 1013-1020

Imbens, G., Kalyanaraman, K., 2012. Optimal Bandwidth Choice for the Regression Discontinuity Estimator. The Review of Economic Studies, Volume 79(3), pp. 933-959

IQ Air, 2019. The 2019 World Air Quality Report, IQ Air

Kusuma, W.L., Chih-Da, W., Yu-Ting, Z., Hapsari, H.H., Muhamad, J.L., 2019. PM2. 5 Pollutant in Asia-A Comparison of Metropolis Cities in Indonesia and Taiwan. International Journal of Environmental Research and Public Health, Volume 16(24), pp. 1-12

Kusumaningtyas, S.D.A., Aldrian, E., Wati, T., Atmoko, D., Sunaryo, S., 2018. The Recent State of Ambient Air Quality in Jakarta. Aerosol and Air Quality Research, Volume 18(9), pp. 2343-2354

Lee, D.S., Lemieux, T., 2010. Regression Discontinuity Designs in Economics. Journal of Economic Literature, Volume 48(2), pp. 281-355

Leviäkangas, P., 2013. Intelligent Transport Systems-Technological, Economic, System Performance and Market Views. International Journal of Technology, Volume 4(3), pp. 288-298

MacDonnel, M., Raymond, M., Wyker, D., Finster, M., Chang, Y., Raymond, T., Temple, B., Scofield, M., Vallano, D., Snyder, E., Williams, R., 2013. Mobile Sensors and Applications for Air Pollutants. US Environmental Protection Agency

Meister, K., Johansson, C., Forsberg, B., 2012. Estimated Short-Term Effects of Coarse Particles on Daily Mortality in Stockholm, Sweden. Environmental Health Perspectives, Volume 120(3), pp. 431-436

Melamed, M.L., Schmale, J., von Schneidemesser, E., 2016. Sustainable Policy-Key Considerations for Air Quality and Climate Change. Current Opinion in Environmental Sustainability, Volume 23, pp. 85-91

Nafila, 0., 2018. Road Space Rationing to Reduce Traffic Congestion: An Evaluation of the OddEven Scheme in Jakarta, Indonesia. Master's thesis, University of Twente

Nieuwenhuijsen, M.J., Dadvand, P., Grellier, J., Martinez, D., Vrijheid, M., 2013. Environmental Risk Factors of Pregnancy Outcomes: A Summary of Recent MetaAnalyses of Epidemiological Studies. Environmental Health, Volume 12(1), pp. 1-10 
Pedersen, M., Giorgis-Allemand, L., Bernard, C., Aguilera, I., Andersen, A.M.N., Ballester, F., Beelen, R.M., Chatzi, L., Cirach, M., Danileviciute, A., Dedele, A., van Eijsden, M., Estarlich, M., Fernández-Somoano, A., Fernández, M.F., Forastiere, F., Gehring, U., Grazuleviciene, R., Gruzieva, O., Heude, B., Hoek, G., de Hoogh, K., van den Hooven, E.H., Håberg, S.E., Jaddoe, V.W.V., Klümper, C., 2013. Ambient Air Pollution and Low Birthweight: A European Cohort Study (ESCAPE). The Lancet Respiratory Medicine, Volume 1(9), pp. 695-704

Proietti, E., Röösli, M., Frey, U., Latzin, P., 2013. Air Pollution During Pregnancy and Neonatal Outcome: A Review. Journal of Aerosol Medicine and Pulmonary Drug Delivery, Volume 26(1), pp. 9-23

Stieb, D.M., Chen, L., Eshoul, M., Judek, S., 2012. Ambient Air Pollution, Birth Weight and Preterm Birth: A Systematic Review and Meta-Analysis. Environmental Research, Volume 117, pp. 100-111

Syafrizal, M., Sugiarto, B., Moersidik, S.S., Fortin, J., Hamani, N., Bretagne, E., 2016. Dynamic Vehicle Emissions Reduction with Technical and Behavioral Approach. International Journal of Technology, Volume 7(5), pp. 871-880

Vallero, D., 2014. Fundamentals of Air Pollution. Academic Press

Viard, V.B., Fu, S., 2015. The Effect of Beijing's Driving Restrictions on Pollution and Economic Activity. Journal of Public Economics, Volume 125, pp. 98-115

Vital Strategies., 2020. Identifying the Main Sources of Air Pollution in Jakarta: A Source Apportionment Study. Available Online at: https://www.vitalstrategies.org/resources/identifying-the-main-sources-of-airpollution-in-jakarta-a-source-apportionment-study, Accessed on 29 July 2021

World Health Organization, 2006. Air Quality Guidelines for Particulate Matter, Ozone, Nitrogen Dioxide and Sulphur Dioxide. Global Update 2005. World Health Organization. Available Online at https://www.euro.who.int/_data/assets/pdf_file/0005/78638/E90038.pdf, Accessed on 29 July 2021

World Health Organization, 2018. Air Quality and Health Fact Sheet. Available Online at http://www.who.int/mediacentre/factsheets/fs313/en/index.html, Accessed on 29 July 2021

Wuragil, Z., 2019. KPBB: Motor Sumbang 45 Persen Polusi Udara Jakarta Per Hari (KPBB: Motorcycles Contribute 45 Percent of Jakarta's Air Pollution Per Day), Tempo. Available Online at https://metro.tempo.co/read/1236898/kpbb-motor-sumbang-45-persenpolusi-udara-jakarta-per-hari, Accessed on 29 July 2021

Ye, J., 2017. Better Safe than Sorry? Evidence from Lanzhou's Driving Restriction Policy. China Economic Review, Volume 45, pp. 1-21

Yudhistira, M.H., Kusumaatmadja, R., Hidayat, M.F., 2019. Does Traffic Management Matter? Evaluating Congestion Effect of Odd-Even Policy in Jakarta. Institute for Economic and Social Research. Working Paper 029

Zhang, M., Shan, C., Wang, W., Pang, J., Guo, S., 2020. Do Driving Restrictions Improve Air Quality: Take Beijing-Tianjin for Example? Science of the Total Environment, Volume 712, https://doi.org/10.1016/j.scitotenv.2019.136408

Zulkarnain, Leviäkangas, P., Tarkiainen, M., Kivento, T., 2012. Electric Vehicles Market Outlook-Potential Consumers, Information Services and Sites Test. International Journal of Technology, Volume 3(2), pp. 156-168 